\title{
Inflammatory Bowel Diseases and diet: an integrative review
}

Regina Márcia Soares Cavalcante

(iD) Murilo Moura Lima²

(D) José Miguel Luz Parente ${ }^{2}$

DMayara Storel Beserra de Moura1

(D) Nadir do Nascimento Nogueira1

1. Pós-Graduação em Alimentos e Nutrição (Doutorado)-PPGAN/Universidade Federal do Piauí (UFPI), Teresina, PI, Brasil. 2. Hospital Universitário da Universidade Federal do Piauí-HU/UFPI, Teresina, PI, Brasil.

\section{SUMMARY}

OBJECTIVE: To gather scientific evidence on the role of diet in inflammatory bowel diseases.

METHODS: Integrative review with studies published in the last 10 years in national and international journals. Original studies developed with adult human beings aged $\geq 18$ years were included and articles published before 2010, literature reviews, and those that did not focus on elements that answered the guiding question were excluded.

RESULTS: 14 articles were selected that addressed important dietary elements in inflammatory bowel disease such as fermentable carbohydrates and polyols, foods of animal origin, foods rich in omega 3, consumption of fruits and vegetables, use of probiotic supplements, whey proteins and soy.

CONCLUSION: The diet, as a potentially modifiable environmental factor, plays an important role in the prevention and treatment of inflammatory bowel diseases. The reduction in the consumption of fermentable carbohydrates and polyols combined with the increase in the consumption of fruits and vegetables as well as the exclusion of products of animal origin such as beef, pork, milk and eggs can help control inflammation and improve the quality of life of patients with inflammatory bowel diseases. The use of probiotics increases food tolerance and, whey and soy proteins, can alter body composition and reduce inflammation.

KEY WORDS: Inflammatory bowel diseases. Diet. Environmental Factors

\section{INTRODUCTION}

Inflammatory bowel disease (IBD) refers to a group of chronic idiopathic inflammatory diseases of the gastrointestinal tract, with symptoms that progressively recur, Crohn's disease (CD) and ulcerative colitis (UC) are the most common clinical forms of IBD'. They are diseases distributed worldwide and represent a significant burden on the health systems in the $21^{\text {st }}$ century. The prevalence of IBDs varies considerably between countries, being more in Europe (CD:322 /100,000 inhabitants in Germany; UC:505/100,000 inhabitants in Norway) and in North America (CD: 319/ 100,000 inhabitants in Canada; UC: 286/100,000 
inhabitants in the United States). However, in recent decades, there have been steady increases in South America, Africa and Asia².

The exact etiopathogenic mechanism of IBD remains unclear, however, it is currently believed that homeostasis between microbiota, intestinal epithelium and immune cells is interrupted by genetic and environmental factors, such as the use of antibiotics, smoking, stress and diet, thus possibly leading to a chronic state of unregulated inflammation ${ }^{3}$. The assumption that the pathogenesis of IBD is significantly influenced by environmental factors has aroused great interest in the identification of potentially modifiable factors for the prevention and treatment of IBD. Constituting one of the bases of this assumption is dysbiotic changes in the intestinal microbiota. In this context research with approaches to manipulating microbiomes has been emphasized, such as the use of prebiotics ${ }^{4}$, probiotics $^{5,6}$, fecal microbiota transplantation ${ }^{7}$ and diet, have been emphasized as possible therapeutic strategies ${ }^{8}$.

In the universe of environmental factors, diet is believed to play an important role in the development of IBD. Although the precise pathophysiological mechanisms remain unknown, many credible explanations have been proposed. First, the diet plays a fundamental role in defining the composition of the human intestinal microbiota and, thus, microbial metabolites ${ }^{9}$. Second, the foods and nutrients associated with the Western diet, characterized by high consumption of red meats, sugary desserts, and foods high in fat and refined grains, have been linked to increased mucosal inflammation, as measured by the fecal calprotectin in humans ${ }^{10}$. Also, experimental studies have shown that the composition of the diet regulates the function of the mucosal barrier, a crucial factor in the pathogenesis of IBD ${ }^{11,12}$.

\section{OBJECTIVE}

The aim of this study was to gather scientific evidence on the role of diet in inflammatory bowel diseases.

\section{METHODS}

The study consists of an integrative literature review, built from original articles that addressed the role of diet in IBD. The study was conducted from January $5^{\text {th }}$ to 15 th, 2020. The elaboration of the manuscript was carried out in stages:
1) Definition of the guiding question: carried out using the PICO strategy, an acronym that represents a problem or population (P), intervention (I), comparison (C) and outcome (O). Thus, the resulting guiding question was: What is the role of diet in inflammatory bowel diseases?

2) Adoption of inclusion and exclusion criteria: Original articles, published in national and international journals, in the last 10 years (2010-2020), carried out with adult human beings (age $\geq 18$ years) were included. Articles published before 2010, literature reviews, and those that did not focus on elements that answered the guiding question were excluded.

3) Search strategy: PubMed, Science Direct and Scielo databases were used to search for articles, using descriptors in Health Sciences (DeCs): Diet and Inflammatory Bowel Disease.

4) Selection of articles: The selection of articles was conducted by two authors independently, and in case of doubt, a third party was consulted. Initially, the titles and abstracts of the selected articles were analyzed to assess whether they met the inclusion and exclusion criteria, and in case of doubt, they were read in full.

\section{RESULTS}

According to the pre-established search criteria, the bibliographic search initially resulted in 61 articles (51 from Pub Med, 09 from Science Direct and 01 from Scielo). After reading the title and summary and applying the inclusion and exclusion criteria, 18 articles were selected (14 from Pub Med, 04 from Science Direct). Through the complete reading of the articles, 14 articles were integrated into the study review at the end (12 from Pub Med and 02 from Science Direct) as shown in Figure 1. After the careful selection process of the articles to be included in this review, the main information was extracted from them, which as grouped in Figure 2.

\section{DISCUSSION}

The analyzed studies showed that several dietary components play important roles in IBD. The use of prebiotics with a beneficial effect on gastrointestinal symptoms and food tolerance in patients with $\mathrm{UC}^{14}$, as well as a study by James et al. ${ }^{21}$, showed that intestinal fermentation of non-starch polysaccharides and starch is reduced in patients with UC, which was not 
FIGURE 1. FLOW DIAGRAM. REGINA MÁRCIA SOARES CAVALCANTE ET AL., 2020.

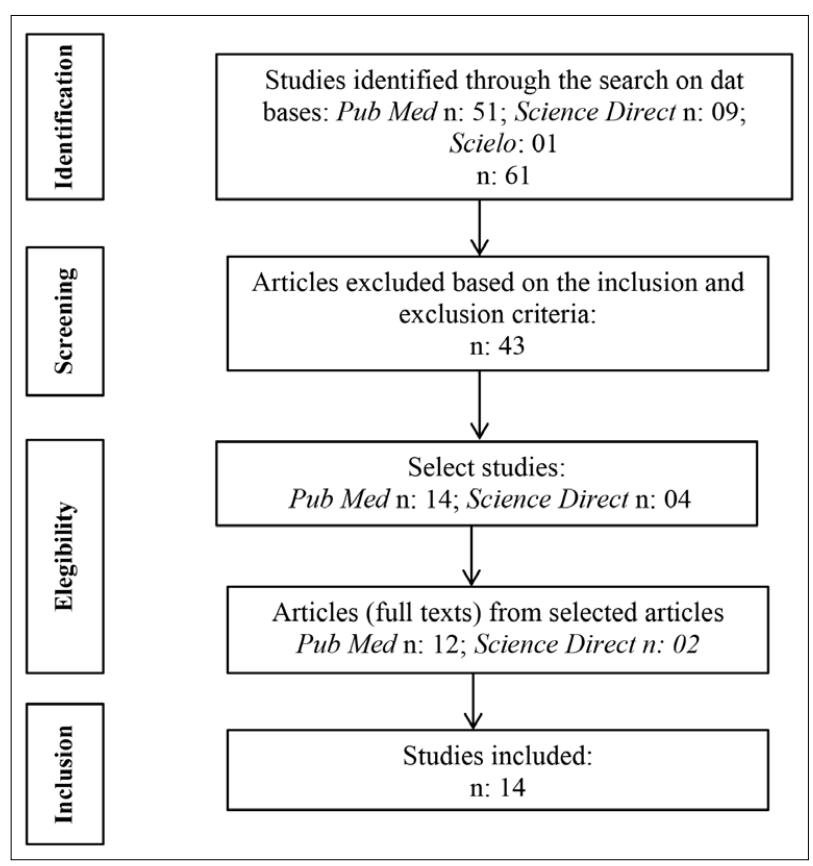

explained by the abnormal intestinal transit and was not corrected by the increased intake of resistant starch/wheat bran. However this can be attributed to the abnormal functioning of the intestinal microbiota.

Diet has a strong connection with the composition of the human intestinal microbiome and microbial metabolites ${ }^{27}$. The genetic loci that are related to the risk of developing IBD can be categorized according to abnormalities in the innate and/or adaptive immune response as well as in the function of the mucosal barrier $^{28}$. Experimental data also suggest that many of these pathways are likely to be influenced by dietary factors $^{29}$. Scientific literature has shown in recent years the growing interest in the use of commensal bacteria or bacteria present in fermented foods, called probiotics, to modulate the intestinal microbiota as well as provide positive effects on the immune system ${ }^{30,31}$. A study by Astó et al. ${ }^{32}$ showed that the use of probiotics seems to be beneficial in achieving remission in patients with UC, using the UCDAI (Ulcerative Colits Disease Activity Index) and DAI (Disease Activity Index) scales to evaluate disease activity as recommended by the FDA for UC clinical trials with pharmaceuticals. It also revealed that probiotics containing bifidobacteria are apparently the most beneficial.

In addition, diet and prebiotics can affect the microorganism-microorganism and microorganism-host interaction, since in addition to the nutritional functions they can also restore intestinal homeostasis and the integrity of the epithelial barrier ${ }^{33}$.
Another highlight among the selected studies was the role of FODMAPs in IBD. A diet low in FODMAPs (oligosaccharides, disaccharides, monosaccharides and fermentable polyols) reduced the typical symptoms of IBDs and increased the quality of life in patients with IBD in remission ${ }^{16}$. From this perspective, a study by Cox et al. ${ }^{17}$ demonstrated that the use of relatively high doses of fructans, except GOS (galacto- oligosaccharides) or sorbitol, exacerbated functional gastrointestinal symptoms-FGS in patients with IBD in remission. Following this line, a survey conducted by Racine et al. ${ }^{19}$ with 1866 people (376 cases and 1490 controls), revealed that there was a positive association between a pattern of consumption of "high sugar and soft drinks" and the risk of UC. When considering foods more associated with the standard, consumers of foods with high sugar and soft drinks were at a higher risk of UC only if they had a low intake of vegetables.

With regard to sugars, FODMAPs, which are highly fermentable carbohydrates and polyols, but little absorbed, were first described in 2005, when the hypothesis was suggested that the rapid fermentation and passage of these substances led to an increase in intestinal permeability, which has been identified as a predisposing factor to IBD in individuals with a genetic predisposition ${ }^{34}$.

With respect to the role of fruits and vegetables, this review presents a study developed by Kim et al. ${ }^{13}$, showing that enriching the diet with mango (Mangifera indica $L$ ) or other foods potentially rich in gallotannin seems to be a promising adjuvant therapy when combined with medications in the treatment of IBD, by reducing inflammation biomarkers and modulating the intestinal microbiota. In this area, a study by Chiba et al. ${ }^{26}$ showed that the adoption of a semi-vegetarian diet was highly effective in preventing relapses in patients with CD.

Regarding the consumption of proteins and fats of animal origin, this review found five studies that addressed this topic. Research carried out by Albenberg et al..$^{15}$, showed that a substantial reduction in the consumption of red and processed meat among patients with asymptomatic CD was not effective in reducing the time of symptomatic relapse. In contrast, research developed by Gunasekeera et al. ${ }^{18}$, concluded that the exclusion diet (milk, beef, pork and egg) guided by IgG4, as an adjuvant, can improve the quality of life and symptoms in patients with CD. In this sense, a study by Machado et al. ${ }^{20}$, showed that 
FIGURE 2. CHARACTERISTICS OF STUDIES INCLUDED IN THE INTEGRATIVE REVIEW. REGINA MÁRCIA SOARES CAVALCANTE ET AL., 2020.

\begin{tabular}{|c|c|c|c|c|}
\hline Authors/year & Sample(n) & Study Design & IBD & Outcomes \\
\hline Kim et al. ${ }^{13}, 2020$ & 10 & Clinical trial & $\begin{array}{l}\text { CD } \\
\text { UC }\end{array}$ & $\begin{array}{l}\text { The enrichment of the diet with mango (Mangifera indica } L \text { ) or } \\
\text { other foods potentially rich in galotanin seems to be a promis- } \\
\text { ing adjuvant therapy combined with conventional drugs in the } \\
\text { treatment of IBD, by reducing inflammation biomarkers and } \\
\text { modulating the intestinal microbiota. }\end{array}$ \\
\hline Sánchez-Morales et al. ${ }^{14}, 2019$ & 34 & Clinical trial & UC & $\begin{array}{l}\text { The administration of a combination of } 6 \text { probiotic strains in } \\
\text { patients with UC has shown a short-term beneficial effect on gas- } \\
\text { trointestinal symptoms, histological findings and food tolerance. }\end{array}$ \\
\hline Albenberg et al. ${ }^{15}, 2019$ & 214 & $\begin{array}{l}\text { Prospective } \\
\text { randomized study }\end{array}$ & CD & $\begin{array}{l}\text { The substantial reduction in the consumption of red and pro- } \\
\text { cessed meat among patients with asymptomatic CD was not } \\
\text { effective in reducing the time of symptomatic relapse }\end{array}$ \\
\hline Pedersen et al. ${ }^{16}, 2017$ & 99 & $\begin{array}{l}\text { Randomized } \\
\text { controlled study }\end{array}$ & $\begin{array}{l}\text { CD } \\
\text { UC }\end{array}$ & $\begin{array}{l}\text { A diet low in FODMAP (Oligosaccharides, Disaccharides, } \\
\text { Monosaccharides and fermentable Polyols) reduced the typical } \\
\text { symptoms of IBDs and increased the quality of life in patients } \\
\text { with IBD in remission. }\end{array}$ \\
\hline Cox et al. ${ }^{17}, 2017$ & 32 & $\begin{array}{l}\text { Randomized, } \\
\text { double-blind } \\
\text { controlled study }\end{array}$ & $\begin{array}{l}\text { CD } \\
\text { UC }\end{array}$ & $\begin{array}{l}\text { The relatively high doses of fructans used, but not GOS (galacto } \\
\text { oligosaccharides) or sorbitol, exacerbated FGS (functional gastro- } \\
\text { intestinal symptoms) in patients with IBD in remission. }\end{array}$ \\
\hline Gunasekeera et al. ${ }^{\mathbf{1 8}}, 2015$ & 76 & $\begin{array}{l}\text { Randomized, } \\
\text { double-blind, } \\
\text { controlled study }\end{array}$ & CD & $\begin{array}{l}\text { The exclusion diet (milk, beef, pork and egg) guided by lgG4, as } \\
\text { an adjuvant, can improve quality of life and symptoms in patients } \\
\text { with CD. }\end{array}$ \\
\hline Racine et al. ${ }^{19}, 2016$ & 1866 & Prospective cohort & $\begin{array}{l}\text { CD } \\
\text { UC }\end{array}$ & $\begin{array}{l}\text { There was a positive association between a pattern of consump- } \\
\text { tion of "high sugar and soft drinks" and the risk of UC. Consumers } \\
\text { of sugar and soft drinks were at higher risk for UC only if they had } \\
\text { a low intake of vegetables. }\end{array}$ \\
\hline Machado et al. ${ }^{\mathbf{2 0}}, 2015$ & 68 & $\begin{array}{l}\text { Randomized } \\
\text { parallel clinical trial }\end{array}$ & $C D$ & $\begin{array}{l}\text { For patients with CD undergoing anti-TNF-alpha and azathio- } \\
\text { prine therapies, supplementation with whey and soy proteins } \\
\text { alters body composition by reducing body fat and contributes to } \\
\text { controlling inflammation. }\end{array}$ \\
\hline James et al. ${ }^{\mathbf{2 1}, 2015}$ & 37 & $\begin{array}{l}\text { Randomized, } \\
\text { blinded, } \\
\text { crossover clinical trial }\end{array}$ & UC & $\begin{array}{l}\text { Intestinal fermentation of non-starch polysaccharides and starch } \\
\text { is decreased in patients with UC, which is not explained by ab- } \\
\text { normal intestinal transit and has not been corrected by increased } \\
\text { intake of resistant starch / wheat bran, which can be attributed to } \\
\text { the abnormal functioning of intestinal microbiota. }\end{array}$ \\
\hline Kyaw et al.22, 2014. & 112 & $\begin{array}{l}\text { Clinical trial } \\
\text { case-control }\end{array}$ & UC & $\begin{array}{l}\text { A probable link between dietary advice and symptomatic } \\
\text { improvement is suggested. The effect of the diet may not occur } \\
\text { through the addition or elimination of unique nutrients; instead, } \\
\text { each food consumed combines many nutrients that allow syner- } \\
\text { gistic or antagonistic action when present in a given composition. }\end{array}$ \\
\hline Brotherton et al. ${ }^{23}, 2014$ & 44 & $\begin{array}{l}\text { Randomized, } \\
\text { blinded, case-control } \\
\text { clinical trial }\end{array}$ & $C D$ & $\begin{array}{l}\text { It is suggested that diet modification may be a welcome comple- } \\
\text { mentary therapy for individuals who suffer from gastrointestinal } \\
\text { disorders associated with CD. }\end{array}$ \\
\hline Grimstad et al. ${ }^{24}, 2011$ & 12 & Clinical Trial & UC & $\begin{array}{l}\text { Ingestion of Atlantic salmon may have beneficial effects on } \\
\text { disease activity in patients with mild UC, based on SCCAI (simple } \\
\text { clinical colitis activity index) and AIFAI (anti-inflammatory fatty } \\
\text { acid index) and a tendency for increased levels of PCR and homo- } \\
\text { cysteine. }\end{array}$ \\
\hline Nolan-Clark et al. ${ }^{25} .2011$ & 165 & $\begin{array}{l}\text { Analytical } \\
\text { observational study }\end{array}$ & $C D$ & $\begin{array}{l}\text { Dairy products in general had no effect on the symptoms of CD, } \\
\text { but items with a high fat content were reported more frequently } \\
\text { in worsening the perceived symptoms of CD. }\end{array}$ \\
\hline Chiba et al. ${ }^{26}, 2010$ & 22 & $\begin{array}{l}\text { Prospective } \\
\text { clinical study }\end{array}$ & $C D$ & $\begin{array}{l}\text { The semi-vegetarian diet was highly effective in preventing } \\
\text { recurrences of CD }\end{array}$ \\
\hline
\end{tabular}

supplementation with whey and soy proteins altered body composition by reducing body fat and, therefore, contributed to control inflammation in patients with CD submitted to anti-TNF-alpha and azathioprine therapies. Clinical trial developed by Grimstad et al. ${ }^{24}$, revealed that the consumption of Atlantic salmon can have beneficial effects on the activity of the disease in patients with mild UC, based on evidence of the simple clinical colitis activity index - SCCAI and anti-inflammatory fatty acid index-AIFAI and a trend towards increased levels of CRP and homocysteine. Research by Nolan-Clark et al. ${ }^{25}$ found that dairy products, in general, had no effect on the symptoms of CD. However, items with a high fat content were reported more frequently in worsening the perceived symptoms of the disease. 
In the pathogenesis of IBD, the importance of the role played by the diet resides in the impact that it can cause in the modulation of clinical symptoms, in the alteration of the intestinal microbiota, and in the improvement of the style and quality of life of those with these diseases ${ }^{34}$. Studies have shown that the adoption of a "westernized" lifestyle, characterized by a diet with a high content of total fats (especially animal fats rich in saturated fatty acids, such as meat and milk fats; foods rich in fatty acids in the series omega-6), refined sugars (rich in monosaccharides and disaccharides) and proteins, and with a low content of fruits and vegetables, potentially increases the risk of developing $\mathrm{IBD}^{35}$. On the other hand, a diet rich in fruits and vegetables, rich in omega-3 fatty acids and low levels of omega- 6 fatty acids have been linked to a decrease in the risk of developing $\mathrm{CD}$ or $\mathrm{UC}^{36}$.

In this sense, to assist in the treatment of IBD, changes in the diet as well as nutritional counseling by a professional trained for this purpose, are necessary. The importance of adopting these measures was evidenced in two studies that integrated this review. A case-control study conducted by Brotherton et al..$^{23}$, suggested that diet modification may be a welcome complementary therapy for individuals with gastrointestinal disorders associated with CD. A similar study regarding the design, developed by Kyaw et al. ${ }^{22}$, suggests that it is likely that there is a link between dietary advice and symptomatic improvement of UC. The effect of the diet may not occur through the addition or elimination of unique nutrients; instead, each food consumed combines many nutrients that allow synergistic or antagonistic action when present in a given composition.

There is growing evidence to suggest a role for diet in the development of IBD, particularly among genetically susceptible individuals ${ }^{37}$. According to Lee et al ${ }^{38}$, dietary interventions can be used to treat patients with active IBD, maintain their remission or even prevent this disease

\section{CONCLUSION}

The pathogenesis of inflammatory bowel diseases, despite having numerous gaps is centered on the breakdown of homeostasis between the intestinal microbiota, the epithelial barrier and immune cells. Currently, it is believed that the interruption of homeostasis is caused by genetic and environmental factors (such as the use of antibiotics, smoking, stress and diet). The role of the diet in these inflammatory diseases has been the focus of many studies, considering that it constitutes a potentially modifiable factor both in the prevention and treatment of these pathologies. Scientific evidence from the past ten years has shown that high consumption of fermentable carbohydrates and polyols combined with low consumption of fruits and vegetables can exacerbate functional gastrointestinal symptoms, and increase the risk of developing IBD and that the gallotannin present in mango can help in controlling inflammation and modulating the intestinal microbiota. The consumption of salmon, rich in omega 3 , as well as the exclusion of foods of animal origin such as milk, beef, pork and eggs has beneficial effects that can improve the symptoms of the disease and the quality of life. In relation to supplementation, probiotics can be used to alleviate some symptoms, such as increasing food tolerance. Supplements with whey protein and soy can help control inflammation by altering body composition. Therefore, this information can support more precise dietary guidelines and assist in the prevention and treatment of inflammatory bowel diseases.

\section{Author's Contribution}

Regina Márcia Soares Cavalcante: conceptualizacion, writing and original draft preparation, research, systematization and analysis of data and final review; Murilo Moura Lima: partial review; José Miguel Luz Parente: partial review; Mayara Storel Beserra de Moura: research, systematization of data; Nadir do Nascimento Nogueira: final review.

\section{RESUMO}

OBJETIVO: Reunir evidências científicas sobre o papel da dieta nas doenças inflamatórias intestinais.

MÉTODOS: Revisão integrativa com estudos publicados nos últimos 10 anos em periódicos nacionais e internacionais. Foram incluídos estudos originais desenvolvidos com seres humanos adultos com idade $\geq 18$ anos e excluídos artigos publicados antes de 2010, revisões de literatura, e os que não apresentassem como foco elementos que respondessem a pergunta norteadora.

RESULTADOS: Foram selecionados 14 artigos que abordaram elementos dietéticos importantes na doença inflamatória intestinal como carboidratos e polióis fermentáveis, alimentos de origem animal, alimentos ricos em ômega 3, consumo de frutas e vegetais, uso de suplementos com probióticos, proteínas do soro do leite e soja. 
CONCLUSÃO: A dieta, como fator ambiental potencialmente modificável desempenha importante papel na prevenção e tratamento das doenças inflamatórias intestinas. A redução no consumo de carboidratos e polióis fermentáveis aliado ao aumento do consumo de frutas e vegetais como também a exclusão de produtos de origem animal como carne bovina, carne suína, leite e ovo podem auxiliar no controle da inflamação e melhoria da qualidade de vida dos pacientes com doenças inflamatórias intestinais. O uso de probióticos aumenta a tolerância alimentar e, proteínas do soro do leite e soja, podem alterar a composição corporal e reduzir a inflamação.

PALAVRAS-CHAVE: Doenças inflamatórias intestinais. Dieta. Fatores Ambientais

\section{REFERENCES}

1. Ng SC, Bernstein CN, Vatn MH, Lakatos PL, Loftus EV Jr, Tysk C, et al. Geographical variability andenvironmental risk factors in inflammatory bowel disease.Gut 2013;62(4): 630-649.

2. Ng SC, Shi HY, Hamidi N, Underwood FE, Tang W, Benchimol El, et al. Worldwide incidence and prevalence of inflammatory bowel disease in the 21stcentury: a systematic review of population-basedstudies. Lancet 2018;390 (10114):2769-2778.

3. Ananthakrishnan, AN. Epidemiology and risk factors for IBD, Nat Rev Gastroenterol Hepatol 2015; 12: 205-17.

4. Laurell A, Sjöberg K. Prebiotics and synbiotics in ulcerative colitis. Scand I Gastroenterol. 2017; 52:477-485.

5. Butterworth AD, Thomas AG, Akobeng AK. Probiotics for induction of remission in Crohn's disease. Cochrane Database Syst Rev. 2008;3:CD006634

6. Mallon P, McKay D, Kirk S, Gardiner K. Probiotics for induction of remission in ulcerative colitis. Cochrane Database Syst Rev. 2007;4:CD005573.

7. Imdad A, Nicholson MR, Tanner-Smith EE, Joseph P Zackular, Oscar G Gomez-Duarte, Dawn B Beaulieu, et al. Fecal transplantation for treatment of inflammatory bowel disease. Cochrane Database Syst Rev. 2018;11:CD012774

8. Limketkai BN, Gordon M, Mutlu EA, De Silva PS, Lewis |D.Diet Therapy for Inflammatory Bowel Diseases: A Call to the Dining Table. Inflamm Bowel Dis. 2019.doi: 10.1093/ibd/izz297.

9. Albenberg LG, Wu GD. Diet and the intestinal microbiome: associations, functions, and implications for health and disease. Gastroenterology 2014; 146:1564-72.

10. Poullis A, Foster R, Shetty A, Fagerhol MK \& Mendall MA. Bowel inflammation as measured by fecal calprotectin: a link between lifestyle factors and colorectal cancer risk. Cancer Epidemiol Biomarkers Prev 2004; 13: 279-84.

11. Martinez-Medina M1, Denizot J, Dreux N, Robin F, Billard E, Bonnet R, Darfeuille-Michaud A, Barnich N.Western diet induces dysbiosis with increased $\mathrm{E}$ coli in CEABAC10 mice, alters host barrier function favouring AIEC colonisation. Gut. 2014;63(1):116-24.

12. Stenman LK, Holma R, Eggert A \& Korpela R A novel mechanism for gut barrier dysfunction by dietary fat: epithelial disruption by hydrophobic bile acids. Am J Physiol Gastrointest Liver Physiol 2013; 304:G227-34.

13. Kim, H., Venancio, V. P., Fang, C., Dupont, A. W., Talcott, S. T., \& Mertens-Talcott, S. U. Mango (Mangifera indica L.) polyphenols reduce IL-8, GRO, and GM-SCF plasma levels and increase Lactobacillus species in a pilot study in patients with inflammatory bowel disease. Nutrition Research 2020. doi:10.1016/j.nutres.2020.01.002.

14. Sánchez-Morales A, Pérez-Ayala MF, Cruz-Martínez M, Arenas-Osuna J, Ramírez-Mendoza P, Ceniceros RA, Mora-Cañas EM, Cruz-Domínguez P Saavedra-Salinas MÁ Efectividad de probióticos sobre síntomas, histología y tolerancia alimentaria en colitis ulcerativa. Rev Med Inst Mex Seguro Soc 2019; 57(1):9-14

15. Albenberg L, Brensinger CM, Wu Q, Gilroy E, Kappelman MD, Sandler RS, Lewis D. A Diet Low in Red and Processed Meat Does Not Reduce Rate of Crohn's Disease Flares. Gastroenterology. 2019;157(1):128-136.

16. Pedersen N, Ankersen DV, Felding M, Wachmann H, Végh Z, Molzen L, Burisch J, Andersen JR, Munkholm P. Low-FODMAP diet reduces irritable bowel symptoms in patients with inflammatory bowel disease. World I Gastroenterol. 2017;14;23(18):3356-3366.

17. Cox, S. R., Prince, A. C., Myers, C. E., Irving, P. M., Lindsay, J. O., Lomer, M. C., Whelan, K. Fermentable Carbohydrates [FODMAPs] Exacerbate Functional Gastrointestinal Symptoms in Patients With Inflammatory Bowel Disease: A Randomised, Double-blind, Placebo-controlled, Cross-over, Re-challenge Trial. Journal of Crohn's and Colitis,2017; 11(12):1420-1429.

18. Gunasekeera, V., Mendall, M. A., Chan, D., \& Kumar, D. Treatment of Crohn's Disease with an IgG4-Guided Exclusion Diet: A Randomized Controlled Trial. Digestive Diseases and Sciences 2016; 61(4):1148-1157.
19. Racine A, Carbonnel F, Chan SS, Hart AR, Bueno-de-Mesquita HB, Oldenburg B, et al. Dietary Patterns and Risk of Inflammatory Bowel Disease in Europe: Results from the EPIC Study. Inflamm Bowel Dis. 2016;22(2):345-54.

20. Machado JF, Oya V, Coy CS, Morcillo AM, Severino SD, Wu C,et al. Whey and soy protein supplements changes body composition in patients with Crohn's disease undergoing.azathioprine and anti-TNF-alpha therapy. Nutr Hosp. 2015;31(4):1603-10.

21. James SL, Christophersen CT, Bird AR, Conlon MA, Rosella O, Gibson PR, Muir JG. Abnormal fibre usage in UC in remission. Gut 2015;64(4):562-70.

22. Kyaw MH1, Moshkovska T, Mayberry J. A prospective, randomized, controlled, exploratory study of comprehensive dietary advice in ulcerative colitis: impact on disease activity and quality of life. Eur | Gastroenterol Hepatol. 2014;26(8):910-7.

23. Brotherton CS, Taylor AG, Bourguignon C, Anderson IG.A high-fiber diet may improve bowel function and health-related quality of life in patients with Crohn disease. Gastroenterol Nurs 2014;37(3):206-16.

24. Grimstad T, Berge RK, Bohov P, Skorve J, Gøransson L, Omdal R, et al. Salmon diet in patients with active ulcerative colitis reduced the simple clinical colitis activity index and increased the anti-inflammatory fatty acid index--a pilot study. Scand J Clin Lab Invest. 2011;71(1):68-73.

25. Nolan-Clark D, Tapsell LC, Hu R, Han DY, Ferguson LR. Effects of dairy products on crohn's disease symptoms are influenced by fat content and disease location but not lactose content or disease activity status in a New Zealand population. I Am Diet Assoc. 2011;111(8):1165-72.

26. Chiba M, Abe T, Tsuda H,Sugawara T, Tsuda S, Tozawa H,et al.Lifestyle-related disease in Crohn's disease: Relapse prevention by a semi-vegetarian diet. World Journal of Gastroenterology,2010; 16(20: 2484.

27. Kau AL, Ahern PP, Griffin NW, Goodman AL, Gordon II. Human nutrition, the gut microbiome and the immune system. Nature 2011; 474: 327-36 (2011).

28. Khor B, Gardet A \& Xavier RJ Genetics and pathogenesis of inflammatory bowel disease. Nature 2011; 474: 307-17.

29. Leone VA, Cham CM,Chang EB. Diet, gut microbes, and genetics in immune function: can we leverage our current knowledge to achieve better outcomes in inflamtory bowel disease?. Curr Opin Immunol. 2014; 0: 16-23.

30. Sánchez, B.;Gueimonde, M.;Peña, A.S.; Bernardo, D. Intestinal microbiota as modulators of the immune system. J Immunol Res 2015;2015:1-14.

31. Scott KP, Antoine JM,Midtvedt T, Van Hemert S. Manipulating the gut microbiota to maintain health and treat disease. Microbiol Ecol Health Dis 2015;26:25877.

32. Astó E, Méndez I, Audivert S, Farran-Codina A, Espadaler J.The Efficacy of Probiotics, Prebiotic Inulin-Type Fructans, and Synbiotics in Human Ulcerative Colitis: A Systematic Review and Meta-Analysis. Nutrients. 2019;11(2). pii: E293.

33. Nagpal R,Yadav H. Bacterial Translocation from the Gut to the Distant Organs: An Overview. Ann Nutr Metab 2017;71(Supp.1):11-6.

34. Knight-Sepulveda K, Kais S,Santaolalla R, Abreu MT. Diet and Inflammatory Bowel Disease. Gastroenterology \& Hepatology 2015;11(8).

35. Hou JK, Abraham B,El-Serag H. Dietary intake and risk of developinginflammatory bowel disease: a systematic review of the literature. Am J Gastroenterol 2011;106:563-573.

36. Forbes A, Escher J, Hebuterne X, Kłek S, Krznaric Z,Schneider S et al. ESPEN guideline: Clinical nutrition in inflammatory bowel disease. Clinical Nutrition 2017;36: 321e347.

37. Khalili H, Chan SSM, Lochhead P, Ananthakrishnan AN, Hart AR, Chan AT.The role of diet in the aetiopathogenesis of inflammatory bowel disease. Nature Reviews Gastroenterology \& Hepatology 2018;15(9):525-535.

38. Lee D, Albenberg L, Compher C, Baldassano R, Piccoli D, Lewis JD, Wu GD. Diet in the Pathogenesis and Treatment of Inflammatory Bowel Diseases. Gastroenterology,2015;148(6), 1087-1106. 